\title{
How do Service Encounters Impact on Relationship Benefits
}

\author{
Chao-Hung Wang \\ Department of Marketing and Logistics Management, Ling Tung University \\ 1 Ling Tung Road, Nantun, Taichung 40852, Taiwan, R.O.C. \\ Tel: 886-4-2389-2088 Ext.3612Ｅ-mail: chw@mail.ltu.edu.tw \\ Li-Chang Hsu (Corresponding author) \\ Department of Finance, Ling Tung University \\ 1 Ling Tung Road, Nantun, Taichung 40852, Taiwan, R.O.C. \\ Tel: 886-4-2389-2088 Ext. $3642 \quad$ E-mail: ltctht87@mail.ltu.edu.tw
}

Received: September 22, 2011

doi:10.5539/ibr.v5n1p98
Accepted: November 23, $2011 \quad$ Published: January 1, 2012

URL: http://dx.doi.org/10.5539/ibr.v5n1p98

\begin{abstract}
The literature has generally held that interpersonal-based service encounters strongly affect the relationship benefits, though technology-based service encounters are increasing importance. However, there has been no systematic comparison of the impact of two service encounters on relationship benefits. We test hypotheses about the respective effects of both service encounters on different relationship benefits in two services industries. The results provide support for the proposal model and indicate that there are higher special treatment benefits when the technology-based service encounter is higher. In addition, the interpersonal-based service encounter has significant positive effect on the confidence benefit. However, the technology-based service encounter leads to significant negative effect on the social benefit.
\end{abstract}

Keywords: Service encounter, Interpersonal, Technology, Relationship benefit

\section{Introduction}

As the services marketplace becomes more competitive, it is increasingly important for core solutions such as physical goods or services to be good enough to provide a competitive advantage. What creates a sustainable competitive advantage is the development of every element in the customer relationship, especially service encounters (Beatson et al., 2007). A service encounter is a process which customers interact directly with a service (Bateson and Hoffman, 2010). If service encounters follow each other in a very brief (e.g., a monthly hair cut service) or over a longer time frame (e.g., an annual tourism package), a relationship may emerge. If a customer experiences continuing valuable contacts with a given provider, a relationship may further develop. Hence, developing value-generating service encounters in the process of a service delivery should be one of the highest priorities in a services marketing strategy (Hogg et al., 2003).

The concept of service encounters has gained increasing attention in services management literature (Simon and Usunier, 2007; Magnus and Rosengren, 2010) during the past decade. Services management academics and practitioners have thoroughly researched this issue, viewing it as one of alternatives for improving service delivery. In the past, service delivery has generally focused on interpersonal-based service encounters (IBSE); however, the service industry is facing huge challenges because of technology innovation. Interpersonal-based service encounters refer to a process in which the service provider always interacts with the customer on a face-to-face base (Lovelock et al., 2009). In contrast, various technologies such as automated teller machines (ATMs) and the Internet have been incorporated into the service delivery process making it possible to create new services (Massad et al., 2006). For example, the Internet enables firms to develop interactive contacts with their customers, and when new elements are added to the service components of customer relationships, these relationships are simultaneously expanded. Generally, a new technology makes it easier to create relationships with customers, but the exact effects of new technologies on customer relationships compared with the IBSE remain relatively unexplored.

When customers interact with the providers, they may use the Internet, ATMs, vending machines, or other electronic interfaces. All these interactions with technological resources are considered technology-based service encounters 
(TBSE), refers to any facility that enables customers to produce services for themselves without assistance from firm employees (Meuter et al., 2005). The development of technology and increased use of the Internet offers new opportunities for service providers to develop their service offerings, such as paying bills from a home computer, using ATMs to withdraw money, or purchasing a travel package through the Internet (Bitner et al., 2000). The use of technology gives customers the advantages of easily and quickly completing the service process.

From the viewpoint of the service sectors, both IBSE and TBSE have the same purposes that would deliver good service processes to customers, create customer loyalty, and establish long term relationships (Fang and Hsu, 2005; Lin, 2007). From the customer viewpoint, whether or not the customer is willing to maintain a relationship with the service provider is subject to the benefits which are generated from the dyadic interaction; namely relationship benefits (Hennig-Thurau et al., 2002). Relationship benefits refer to a customer's feeling trust, or social and special treatment bonds that have been established between the parties (Grönroos, 2007). While relationship benefit is often included as an outcome variable in customer relationship management, the comparison between the two kinds of service encounter and the various relationship benefits received relatively little research attention. We attempt to compare the respective effects of IBSE and TBSE on the relationship benefits because comparing the effect of different service encounters increases the understanding of relationship benefits. The differentiation of the service encounters and their impacts on relationship benefits should be a significant issue for services management academics and practitioners.

\section{Theoretical Background and Hypotheses}

This study has segmented service encounters into two levels of interaction, representing the extent of interaction with service personnel and with technological elements. Figure 1 depicts the causal relationships between service encounters and relationship benefits from these encounters. More specifically, the Figure 1.shows the separate effect of two service encounters (i.e., IBSE and TBSE) on the three different concepts of relationship benefits (i.e., special treatment benefit, confidence benefit, and social benefit), as discussed in the following sections.

Insert Figure 1 Here

Customers evaluate the benefits which have occurred in the core service offerings and the dyad relationship, and then decide to whether establish and maintain the relationships with the provider (Beatty et al., 1996). Gwinner et al. (1998) distinguished between three types of relationship benefits: special treatment benefit, confidence benefit, and social benefit. The differences between these benefits reflect the relationships that bind the customer to the provider. Customers are actively involved with the service provider and its personnel during service delivery (Singh and Tor, 2008). All people-processing services have high levels of contact such as medical services, management consulting, or car repairing. IBSE is concerned with personal interaction and dual communication of participants toward the transaction which they are involved in (Suprenant and Solomon, 1987; Keillor et al., 2004). The basic value of IBSE is perceived in various ways, depending on how friendly and kindly the interactions are perceived, and how well customers understand their provider's role in the service delivery (Noone et al., 2009).

When the service provider succeeds in providing special treatment benefit (e.g., customized service) to its customer based on a high level of face-to-face interaction, each customer is treated as a specialized segment (Dolen et al., 2004). Special treatment benefit is defined in terms of saving time, discount price, or special rewards (Bettencourt and Gwinner, 1996). A customer may have encounters with different IBSEs (e.g., customer-contact personnel, the ordering department, and the billing department). The customer's positively evaluation of the experiences with the different IBSEs, along with the repeated discrete transactions, will create an overall customer perception of satisfaction with IBSE, and then will feel the special treatment benefit (Riley, 2007).

Dolen et al. (2004) also posited that salespersons supply customerization service according to limited cues from customers (e.g., tone, attitude, clothing, and age). Hotels, for example, capture their customers' preferences by satisfying their customers' special demands. When those customers arrive at the hotel, they experience friendly contact during check-in and find that their individual needs have already been anticipated, from offering priority reservations to preferred drinks in the room refrigerator. Thus, when the service provider has a stable customer base with satisfied customers who through positive word-of-mouth referrals of good IBSE may bring in new customers, in principle nothing else than traditional marketing activity is needed. Because of a customer-focused IBSE and consequently a successful interpersonal interactive process, the customers satisfied enough to generate the special treatment benefit (Cowley et al., 2005; Sujan et al., 1998). Hence:

H1: IBSE will be positively related to the customer's special treatment benefit.

Confidence benefit is generally referred to as a type of trust and a perceived low level of risk in long term relationships (Morgan and Hunt, 1994; Heffernan, 2004). Trust is created through dialogue, conversation, gestures, 
and other interpersonal communication (Bruhn, 2003). As Homans (1950) argued, trust is produced through a gradual process of interpersonal interaction. In IBSE, a customer can directly communicate with the service providers, and so the dyad is more likely to communicate the mutual intention (Patterson and Smith, 2001). There are a number of IBSE between the service provider and the customer, including various series of moments of truth. The accessibility of a restaurant or a business consultant, the appearance and behavior of waiting staff, bank staff, travel agency representatives, and how these service employees perform their task, what they say and how they do it also influence the customer's confidence (Wang et al., 2009).

In the context of service delivery, customers must rely on providers to give credence to the contact since their information largely depends on the provider's honesty. A customer, thus, can perceive the level of trust in a service encounter, reduce uncertainty, and lower anxiety. In addition to the trust in dyadic interactions, warm feelings are often cited as one of reasons for choosing a provider in service delivery (Bendapudi and Berry, 1997). Relationship management activities by providers are often geared towards achieving the customer's confidence by information-sharing on dyadic exchanges and the cooperative attitude of interpersonal interaction (Sweeney and Webb, 2002). For instance, in the banking industry an honest information exchange (e.g., customers' credit evaluation) will encourage bank managers to work more closely with their customers. Thus, we posit that the better IBSE will inspire customer confidence benefit.

H2: IBSE will be positively related to the customer's perceived confidence benefit.

The concept of social benefit is frequently associated with friendship, affinity, and belongness (Goodwin, 1997; Price and Arnould, 1999). It is typically based on personal relationships between providers and customers (Suprenant and Solomon, 1987). As the IBSE is central to the customer's satisfaction perception, we would expect a positive relationship between IBSE and social benefit. For example, hairdressing is highly interpersonal service encounter. When a customer goes for a haircut, the hairdresser addresses customer by name or asks why he hasn't been in for a long time. A provider that has maintained mutual interpersonal relationships with a level friendship has a better change of creating the social benefit (Gremler and Gwinner, 2000). In other words, the interpersonal relationships that exist between customer and employee foster the development of affinity between the parties (Raajpoot, 2004).

Indeed, interpersonal interaction between customers and employees leads customers to have higher levels of belongness to the service providers (Reynolds and Beatty, 1999). The interaction between customers and employees is central to the interpersonal contact in many services, and social benefits are desired by the customer. Gremler and Gwinner (2000) indicate that customer-employee rapport is significantly related to social benefit. A positive relationship between commercial friendships is a key element of social benefit. Thus, we propose that a personal interaction between a customer and a service employee fosters a social relationship. Consequently, it is posited that:

H3: IBSE will be positively related to the customer's perceived social benefit.

A serviced encounter consists of a service outcome (i.e., what the customer receives during the exchange) and the process of service delivery (i.e., the way the outcome delivered to the customer) (Jayawardhena et al., 2007). Customer satisfaction with TBSE, by visiting its website, navigating through it, searching for product and service information, is therefore a combination of the customer's satisfaction with the service outcome and with the process of service delivery (Namasivayam and Hinkin, 2003). More specifically, technology developments enable providers to create new services more easily and customers to experience service processes more clearly (Bitner et al., 2000). Meuter et al. (2000) discussed the causes of satisfaction/dissatisfaction with self-service technology, finding that the major satisfaction factor is that the process is completed more quickly and easily than with traditional alternatives.

Customers can perceive the high autonomy and special rewards while they use a technological interface to complete the exchange (Bauer et al., 2006). Patricio et al. (2003) posited that in the banking industry a highly competitive marketplace has forced banks to add more services through new technological interfaces in order to increase customer's benefits. Many customers can appreciate special treatment from TBSE such as benefiting from time and cost savings, flexibility, convenience of location, greater control over service delivery, and a higher perceived level of customization. Another stream of research has explored online shopping (Janda et al., 2002). If customers are satisfied with price savings, time saving, and personalization of merchandise selection through TBSE, then we can expect that they will continue to use these technical facilities. We posit that the importance of the higher degree of the technology interaction is significant in customers' evaluating special treatment benefit. Hence:

H4: TBSE will be positively related to the customer's perceived special treatment benefit.

New technological solutions make it possible to compile, store, disseminate, and retrieve data in ways that make it safer and more easily available to larger numbers of customers than ever before (Walker et al. 2002). When 
providers can deliver safe and low-risk information to their customers, the confidence benefits occur in a dyadic relationship (Kang and Kim, 2006; Mcknight et al., 2002). Customers also appreciate TBSE when it is more effective than being served by a service employee, enabling customers to get detailed information and complete transactions more reliably than they could through direct contact (Zhu et al., 2002).

Receptivity to technological tool was theorized to have a positive relationship with confidence benefit, since TBSE is mainly concerned with the establishment of e-trust (Hsu and Wang, 2008). A customer with higher receptivity to TBSE is more likely to show greater confidence with the website. We argue that technological tools in an exchange will reduce anxiety and increase confidence in the service process. This assertion is partially based on the notion that greater levels of TBSE in the interaction will enable contact customers to obtain easily retrievable and reliable information (Jarvenpaa et al., 2000). Appropriate technology may improve working conditions, enhance the motivation of the employees to provide good service, and increase the success rate of the service process, thereby leading to greater confidence in the provider. Logically speaking, when customers are satisfied with their TBSE, they are more likely to be committed to the service providers (Kim and Prabhakar, 2004; Kim et al., 2005). In other words, if a customer is satisfied with the TBSE, they are more likely to trust the provider, suggesting that TBSE leads to confidence benefits. Based on the above argument, the following hypothesis related to confidence benefits is proposed:

H5: TBSE will be positively related to the customer's perceived confidence benefit.

Though a technological interaction typically involves no direct interaction with other people, this does not mean that a friendship cannot be nurtured (Gefen et al., 2003). For example, many websites add a "social touch" to the website, personalizing website communications (Gefen and Straub, 2004). Undoubtedly, TBSE could build social benefits through the perception that the TBSE has a sense of sociable and sensitive human contact (Hampton-Sosa and Koufaries, 2005). From a customer perspective, such attributes are clearly desirable. Yoon (2002) believed that the personal variables such as receptivity to technology, familiarity with Internet, prior satisfaction with website experience might precede the formation of online confidence benefit. These personal variables were derived from the promise that past experience with TBSE provides importance clues for judging the desirability of the future purchase.

Balance theory (Heider, 1958) posits that people tend to develop social relationships toward those with whom they have some prior association. When customers have had more experience with technological facilities, they experience more belongness and affinity. This leads customers to be more willing to accept the technological interaction (Menor and Roth, 2007). Therefore, customer technological interactions can be argued to be positively related to social benefits. Finally, customers satisfied with the overall TBSE are likely to feel they have a vested interest in staying with that technological service since the costs to go elsewhere may be too high. If a customer has a positive experience on TBSE, it is likely that they will want to stay with the same technology service rather than spend the time and effort to find another, while risking that the new service will be poor. This therefore, implies a positive impact of TBSE on social benefit. Hence,

H6: TBSE will be positively related to the customer's perceived social benefit.

\section{Methodology}

\subsection{Selection of Services and Descriptive Statistics}

An externally valid, fuller understanding of service encounters requires that the validity of conceptual models developed in one setting be examined in other settings as well. Two service industries (hotel and banking) were selected to test the critical dimensions that might influence the relationship benefits. A review of the major classification scheme (Lovelock, 1996) formed the basis for selecting these two services. The industries differ in many dimensions. For example, interpersonal features of encounter might be expected to be more important in the hotel context since it is characterized by a higher degree of personal contact. Like hotels, the banking industry also has a mix of interpersonal and technological encounter (Bitner, 2001; Curran et al., 2003). Technological features might be more important in relationships between the banking industry and customers who prefer anonymous self-service. In both cases, customers know very easily if they are satisfied by the service provider, interpersonally or technologically. It is considered that these two services were sufficiently different between IBSE and TBSE to allow for generalizing the results beyond a single service setting.

\subsection{Data Collection and Measures}

The data were collected from real customers of hotels $(n=225)$ and banks $(n=225)$, for a total of 450 questionnaires. After the elimination of 26 questionnaires (hotel=12; banking=14), which had an excessive amount of mistake data (above $3 \%$ of data points), the final sample consisted of 424 respondents. The participants of this study varied 
adequately in terms of demographic variables. Most of the respondents were predominately 20 to 40 years of age (hotel: $72.1 \%$; bank: $64.6 \%$ ), with $43.2 \%$ of respondents male and $56.8 \%$ female. A questionnaire was developed on the basis of literature and qualitative interviews. The study commenced with a qualitative research phase. During this phase, 30 persons out of all who were contacted were asked to participate in in-depth interviews. The purpose of the interviews was to understand the underlying issues of provider/adviser-client encounters. The literature review, discussed in the background section, provided the basis for the items used to measure the constructs. Five-point Likert scales ranging from $1=$ strongly disagree to $5=$ strongly agree were used to measure the study constructs. The IBSE was measured by the modification of the courtesy, communication, and understanding of Parasuraman et al. (1985). Respondents were asked to rated the service provider's degree of involvement and interaction in the service process. For example, to measure the provider's communication, responds were asked to indicate their attitude concerning the personalized attention from the providers. Responses to the four items were summed to derive the overall composite IBSE score for the each subject.

TBSE was opersationalized by a 4-items measurement, which was recommended by Bitner et al. (2000) and Meuter et al. (2000). For instance, one measure was obtained by the following question "In service process, my needs would be fulfilled by the technological equipment such as Internet and ATM". To operationalize the relationship benefit, we used 11 items that sought to evaluate various relationship benefits, which was adapted from scales developed and validated by Gwinner et al. (1998), Hennig-Thurau et al. (2002), and Patterson and Smith (2001). Special treatment benefit and confidence benefit both included four items, respectively. The remaining three questions were related to social benefit.

\subsection{Measurement Model Evaluation}

We proposed a set of multiple item reflective scales to measure each construct. Face validity appears evident, and the conceptual definition match well with the item wordings. Additionally, a simple pretest was performed in which our research team matched items with the construct names. No one had difficulty matching items to constructs, providing further confidence the scales contain face validity. Furthermore, measure validation began with preliminary exploratory factor analysis and reliability analysis to purify the scales and ensure consistency of the items. In the exploratory analysis, evidence for the unidimensionality of each construct was based on the principal components analysis with varimax rotation. This revealed that the appropriate items loaded at least 0.7 on their respective hypothesized component, with a loading no larger than 0.5 on other components. In the confirmatory factor analysis (CFA), the reliability of scales was assessed using the composite reliability, and all exceeded 0.75 . Table 1 contains the results of exploratory factor analysis and reliability analysis for IBSE, TBSE, and relationship benefits.

We tested convergent and discriminant validity of the scales with confirmatory factor analysis (CFA). We first assessed convergent validity by two reliability indexes for each construct based on the estimated measurement model. All $\mathrm{t}$-values of the estimated factor loadings of the five theoretical constructs are significant $(\mathrm{p}<0.01)$. All theoretical scales are above the recommended level of composite reliabilities $(0.7)$ and extracted variance $(0.5)$ (Fornell and Larcker, 1981). Convergent is satisfactory. Accordingly to the criteria recommended by Fornell and Larcker (1981), a CFA with the five dimensions as latent constructs confirms discriminant validity between the dimensions. In this case, goodness-of-fit statistics are 333.82, degree of freedom $(\mathrm{df})=142$, average goodness-of-fit $(\mathrm{AGFI})=0.869$, root mean square error of approximation $($ RMSEA $)=0.064$. The nomological validity of constructs involved in the model can be observed in the correlations between constructs. More specifically, the directions of all relationships hypothesized in the model were supported. Strong evidence of nomological validity was demonstrated.

Insert Table 1 Here

\section{Results}

Means and standard deviations were computed for all variables in the model TBSE has a mean score of 3.18, which is slightly above the mid-point of 2.5. In contrast, IBSE has a mean score of 3.68 showing that customers reported a higher level of information to IBSE than to TBSE. Among the three constructs of relationship benefits, customers rate the confidence benefit as the most important (3.83) and give less weight to the other two constructs (2.23 for special treatment benefit and 3.2 for social benefit).

Insert Table 2 Here

To test the hypotheses, we used AMOS 6.0 to obtain maximum likelihood estimates of the standardized path coefficients. It can be concluded that the fit of this model is good: $\chi^{2}=432.07, \mathrm{df}=145$, comparative fit index (CFI) $=0.92, \mathrm{AGFI}=0.839, \mathrm{RMSEA}=0.078$. All goodness of fit measures well exceed the recommended cut-off values, Furthermore, the values of the $\chi^{2} / d f$ is 2.979 , which can be considered adequate. 
With regard to the special treatment benefit, Hypotheses 1 and 4 state that IBSE $(\beta=0.275, t=4.191, p<0.01)$ and TBSE $(\beta=0.389, \mathrm{t}=5.714, \mathrm{p}<0.01)$ are positively related to customers' special treatment benefits. These two hypotheses are strongly supported by the data, indicating that IBSE and TBSE contribute to the way in which customers feel about the special treatment with their providers. Significant positive relationships were found between IBSE and confidence benefits $(\beta=0.497, t=5.493, p<0.01)$. Hence, hypothesis 2 was supported, but TBSE has non-significant positive effect on confidence benefits $(\beta=0.078, \mathrm{t}=1.457, \mathrm{p}>0.1)$. Thus, Hypothesis 5 was not supported. With greater IBSE in a service process, higher the confidence relationships will be nurtured by customer and provider. As expected, IBSE also has a positive effect on social benefit $(\beta=0.793, \mathrm{t}=6.553, \mathrm{p}<0.01)$, hence, Hypothesis 3 is supported. Thus the customer and the provider find that they can establish and maintain a friendly atmosphere in this interpersonal communication. The intent of this interaction is to build shared values, and better understand what the two parties can do together.

We also find a non-significant positive relationship between TBSE and social benefits $(\beta=0.107, t=1.759, p>0.05)$, Hypothesis 6 was not supported. Thus, when more technical equipment is used in service process, it may not be lead to more feeling of friendship and closeness between the relationship of customer and service provider. This finding deserves more attentions and discussions in following section.

\section{Discussion}

The contribution of this study is that it elucidates the interaction process between the service encounters and relationship benefits, and thus provides managerial implications of how providers can better create relationship benefit with customers.

\subsection{Comparing the Impact of IBSE and TBSE on Special Treatment Benefit}

With respect to the specific treatment benefit, our results provide support for a positive relationship between IBSE and specific treatment benefit, and TBSE and specific treatment benefit. This finding suggests that the effect of TBSE on special treatment benefit is greater than the effect of IBSE. But the results do not completely show that the provider needs to focus on the TBSE while neglecting IBSE. The potential explanation for this finding might be that if the provider uses the technological standard process (e.g., ATMs), these TBSEs are adequate for routinely contact (Meuter et al., 2000). This finding is congruence with Li and Zhang (2005). Thus, these empirical results are good news for management since they suggest that upgrading technology leads to higher special treatment benefit in general situations and better efficiency in the service process (Bitner et al., 2000).

Another likely explanation for this is that individual customers do not appreciate being openly favored above others, which leads customers preferring TBSE to IBSE. If this is true, the important implication for providers is they should carefully treat customers in order to avoid bringing them into an embarrassing position through interpersonal interaction.

\subsection{Comparing the Impact of IBSE and TBSE on Confidence Benefit}

With respect to confidence benefit, we find that IBSE has a positive impact on this relationship benefit. From a managerial viewpoint, the confidence benefits of customers can only be achieved if customers and employees trust each other. The interdependence of customers and employees can make customers are confident that the provider will continue to provide high-touch service. This interpersonal interaction must be in an IBSE since the IBSE always has an interpersonal emotional component. Providers who maintain good communication with their customers always attempt to reach beyond the economic aspect of their service to create feelings of trust and closeness.

The empirical findings also indicate the possible effect of TBSE on confidence benefit. According to the electronic commerce literature, technology can play an important role in nurturing dyadic trustworthiness and closeness (Kim and Prabhakar, 2004; Mcknight et al., 2002), but our empirical findings fail to confirm this expectation. Trust is known to be crucial in relationship marketing (Morgan and Hunt, 1994), and a way to reduce the perceived risk and uncertainty when dealing with technology. In interpersonal interactions, the physical presence of a service provider (e.g., customer-contact staff) inspires customer trust. Transacting with technological contact, however, involves a certain degree of risk and uncertainty because the behaviors of a service provider are less guaranteed in technology interactions than in personal contact (Hwang and Kim, 2007).

Another potential explanation is that the increasing growth of new technologies, the deliveries of services, the ability and willingness of customers to use these new technologies are considered as a technology anxiety, which is actually a common occurrence (Meuter et al., 2003). Technology anxiety leads customers to have reduced faith in the provider than with interpersonal interaction (Thatcher and Perrewe, 2002). Thus, the best strategy for managers is to make their customers feel more secure by reducing the use of technology where the customers are located. In other words, to foster close long-term relationships, managers need to understand their customers' state of mind about new 
technology.

This finding also supports the following important managerial implications. If the customers have only discrete encounters that occur over a short time period, the case of technology should dominate. In contrast, if the customer-provider relationship is a more continuous encounter, more interpersonal interaction should be involved to meet the need for personal affection. Because the technology interface is not appropriate for the non-routine and complex continuous contact, IBSE is necessary to cope with constantly changing customer needs.

\subsection{Comparing the Impact of IBSE and TBSE on Social Benefit}

We find that the social benefit is relatively strongly determined by IBSE. This result demonstrates the impact of personal involvement on the customers' relationship maintained with a provider. Several studies have also stressed that findings of studies on interpersonal contacts can be transferred to social relationships (Shim and Eastlick, 1998). In other words, customers' inclination to engage in interpersonal interactions would be stronger when these interactions help to satisfy the need for social recognition.

Interestingly, we find a significant negative relationship between TBSE and social benefits. This finding is contrary to the literature, it requires special attention in service marketing research. One plausible explanation for this diversity connection is that high level of interaction properties inherent in social benefits may leave TBSE unable to deliver the value of service encounter. Because new techniques are added to the service process, the relationship of the customer and the provider is expanded and changed. As the relationship grows in scope, more functions are in immediate contact with customers such as bank tellers, service technicians, and contact center systems. These TBSEs maybe decrease the feeling of friendship and closeness of the buyer-seller relationship.

Our study is also valuable for management, since it differentiates IBSE and TBSE to develop a better understanding of why social benefit will be satisfied. In order to identify customers who have a preference for interpersonal interaction, the provider should carefully apply technical resources and avoid excessive use of technology. Furthermore, service provider pays more attention to the technology interaction and higher frequencies using the TBSE with customers, there is evidence that customers sometimes perceive the TBSE in a negative light. This finding is congruence with the past research (Curran et al., 2003). When customers are not comfortable with the TBSE, they may find it intimidating and may foresee service recovery trouble because they are not able to communicate with a staff member for help, ultimately resulting in the unexpected effect and an obvious risk of losing customers.

\section{Conclusions}

The primary importance of this study is its support for interpersonal-based and technology-based service encounters in the interaction between customers and providers. This in turn depends on the attitudes of employees and how they interact with customers. TBSE focuses more on interactions with various technical service provisions. As a result, the relative importance of relationship benefit may vary between the two types of encounters. Thus, a comprehensive service encounter concept should be used as a strategic guideline because providers have to adjust the operations or administrative systems of the organization to satisfy various customers' needs. Providers sometimes also have to use technical offerings as well as get in contact with customers in person. More specifically, providers have already prepared a set of human and technical resources that affect which resources are going to be used. If all these interactions are considered complicated and unfriendly, the perception of relationship benefit will likely be low.

Overall, our study has shown that developing the relationship benefits is a highly integrated process. A good service encounter cannot occur without considering the interpersonal and technical aspects in the service process. In other words, the well planned introduction of an additional service offering or new technical equipment may become a powerful source of competitive advantage.

Some limitations of the present study and direction for future research should be mentioned. One limitation is that we distributed the questionnaires with only a fraction of the surveys in the banking and restaurant settings. Clearly more research is needed to broaden the database for further generalizations. Replications to validate the conceptual model proposed should consider other service sectors (e.g., automobile repair, airline and department store) and service domains (e.g., an experienced and novice customes) (Johnson and Mathews, 1997). Research along this line could lead to a contingency framework by showing the correlation between service encounters and relationship benefits.

In addition, due to the dynamic nature of relationships, interactions between customers and contact employees or technological tools are seldom static and are likely to change over time. This is because the participants in the interactions may react differently, depending on the different phases in the relationship development. Thus, future 
research should consider the need for longitudinal research, since longitudinal research designs may be needed to explore how relationship benefits change over time, as customers proceed through various phases of relationship development.

It would be a logical next step to investigate the moderating effects of relationship proneness, technology anxiety, and technology proneness on IBSE. Our understanding of the service delivery process would undoubtedly be enriched with further study of this complicated interactive influence.

\section{References}

Bauer, H. H., Falk, T., \& Hammerschmidt, M. (2006). eTransQual: A Transaction Process-Based Approach for Capturing Service Quality in Online Shopping. Journal of Business Research, 59(1), 866-875. http://dx.doi.org/10.1016/j.jbusres.2006.01.021

Beatson, A., Lee, N., \& Coote, L. (2007). Self-Service Technology and the Service Encounter, Service Industries Journal, 27(1), 70-89. http://dx.doi.org/10.1080/02642060601038700

Beatty, S. E., Mayer, M., Coleman, J. E., Ellis-Reynolds, K., \& Lee, J. (1996). Customer-Sales Associate Retail Relationships. Journal of Retailin, 72(3), 223-247. http://dx.doi.org/10.1016/S0022-4359(96)90028-7

Bendapudi, N., \& Berry, L. L. (1997). Customers' Motivations for Maintaining Relationships with Service Provider. Journal of Retailing, 73(1), 15-37. http://dx.doi.org/10.1016/S0022-4359(97)90013-0

Bettencourt, L. A., \& Gwinner, K. P. (1996). Customization of the Service Experience: The Role of the Frontline Employee. International Journal of Service Industry Management, 7(2), 3-13. http://dx.doi.org/10.1108/09564239610113442

Bitner, M. J., Brown, S. W., \& Meuter, M. L. (2000). Technology Infusion in Service Encounters. Journal of the Academy of Marketing Science, 28(1), 138-149. http://dx.doi.org/10.1177/0092070300281013

Bitner, M. J. (2001). Services and Technology: Opportunities and Paradoxes. Managing Service Quality, 11(6), 375-370. http://dx.doi.org/10.1108/09604520110410584

Bruhn, M. (2003). Relationship Marketing: Management of Customer Relationship, New York: Prentice Hall.

Cowley, E., Farell, C., \& Edwardson, M. (2005). The Role of Affective Expectations in Memory for a Service Encounter. Journal of Business Research, 58(10), 1419-1425. http://dx.doi.org/10.1016/j.jbusres.2003.10.011

Curran, J. M., Meuter, M. L., \& Suprenant, C. F. (2003). Intentions to Use Self-Service Technologies: A Confluence of Multiple Attitudes. Journal of Service Researc, 5(3), 209-224. http://dx.doi.org/10.1177/1094670502238916

Dolen, W., Ruyter, K., \& Lemmink, J. (2004). An Empirical Assessment of the Influence of Customer Emotions and Contact Employee Performance on Encounter and Relationship Satisfaction. Journal of Business Research, 57(4), 437-444. http://dx.doi.org/10.1016/S0148-2963(02)00277-1

Fang, S. R., \& Hsu, C. P. (2005). The Impacts of Technology-Based and Interpersonal-Based Service Encounter on Relationship Benefits. Management Review, 24(2), 53-76.

Fornell, C., \& Larcker, D. J. (1981). Evaluating Structual Equation Models with Unobservable Variables and Measurement Error. Journal of Marketing Research, 18(1), 39-50. http://dx.doi.org/10.2307/3151312

Gefen, D., Karahanna, E., \& Straub, D. W. (2003). Trust and TAM in Online Shopping: An Integrated Model. MIS Quarterly, 27(1), 51-90. http://dx.doi.org/10.2307/30036519

Gefen, D. \& Straub, D.W. (2004). Consumer Trust in B2C E-Commerce and the Importance of Social Presence: Experiments in E-Products and E-Services. Omeg, 32(6), 407-424. http://dx.doi.org/10.1016/j.omega.2004.01.006

Goodwin, C. (1997). Communality as a Dimension of Service Relationships. Journal of Consumer Psychology, 5(4), 387-415. http://dx.doi.org/10.1207/s15327663jcp0504_04

Gremler, D. D., \& Gwinner, K. P. (2000). Customer-Employee Rapport in Service Relationships. Journal of Service Research, 3(1), 82-104. http://dx.doi.org/10.1177/109467050031006

Grönroos, C. (2007). Service Management and Marketing: A Customer Relationship Management Approach. New York: John Wiley and Sons.

Gwinner, K. P., Gremler, D. D., \& Bitner, M. J. (1998). Relational Benefits in Services Industries: The Customer's Perspective. Journal of the Academy of Marketing Science, 26(2), 101-114. http://dx.doi.org/10.1177/0092070398262002

Hampton-Sosa, W., \& Koufaris, M. (2005). The Effect of Web Site Perceptions on Initial Trust in the Owner 
Company. International Journal of Electronic Commerce, 10(1), 55-81.

Heffernan, T. (2004). Trust Formation in Cross-Cultural Business-to-Business Relationships. Qualitative Market Research, 7(2), 114-125. http://dx.doi.org/10.1108/13522750410530020

Heider, F. (1958). The Psychology of Interpersonal Relations. New York: John Wiley and Sons.

Hennig-Thurau, T., Gwinner, P., \& Gremler, D. (2002). Understanding Relationship Marketing Outcomes: An Integration of Relational Benefits and Relationship Quality. Journal of Service Research, 4(3), 230-247. http://dx.doi.org/10.1177/1094670502004003006

Hogg, G., Laing, A., \& Winkelman, D. (2003). The Professional Service Encounter in the Age of the Internet: An Exploratory Study. Journal of Services Marketing, 17(4-5), 476-49. http://dx.doi.org/10.1108/08876040310486276

Homans, G. (1950). The Human Group. New York: Harcourt.

Hsu, L. C., \& Wang, C. H. (2008). A Study of E-Trust in Online Auction. Journal of Electronic Commerce Researc, 9(4), 310-321. [Online] Available: http://www.csulb.edu/web/journals/jecr/issues/20084/index.pdf.

Hwang, Y., \& Kim, D. J. (2007). Customer Self-Service Systems: The Effects of Perceived Web Quality with Service Contents on Enjoyment, Anxiety, and E-Trust. Decision Support System, 43(3), 746-760. http://dx.doi.org/10.1016/j.dss.2006.12.008

Janda, S., Trochia, P., \& Gwinner, K. (2002). Consumer Perceptions of Internet Retail Service Quality. International Journal of Service Industry Managemen, 13(5), 412-431. http://dx.doi.org/10.1108/09564230210447913

Jarvenpaa, S., Tractinsky, N., \& Vitale, M. (2000). Consumer Trust in an Internet Store. Information Technology and Management, 1(1-2), 45-71. http://dx.doi.org/10.1023/A:1019104520776

Jayawardhena, C., Souchon, L. A., Farrell, M. A., \& Ganville, K. (2007). Outcomes of Service Encounter Quality in a Business-to-Business Context. Industrial Marketing Managemen, 36(5), 575-588. http://dx.doi.org/10.1016/j.indmarman.2006.02.012

Johnson, C., \& Mathews, B. P. (1997). The Influence of Experience on Service Expectations. International Journal of Service Industry Management, 8(4), 290-305. http://dx.doi.org/10.1108/09564239710174381

Keillor, B. D., Hult, G. T., \& Kandemir, D. (2004). A Study of the Service Encounter in Eight Countries. Journal of International Marketing, 12(1), 9-25. http://dx.doi.org/10.1509/jimk.12.1.9.25649

Kang, Y., \& Kim, Y. (2006). Do Visitors' Interest Level and Perceived Quality of Web Page Content Matter in Shaping the Attitude Toward a Web Site? Decision Support System, 42(2), 1187-1202. http://dx.doi.org/10.1016/j.dss.2005.10.004

Kim, K., \& Prabhakar, K. (2004). Initial Trust and the Adoption of B2C E-Commerce: The Case of Internet Banking. Data Base for Advances in Information System, 35(2), 55-64. http://dx.doi.org/10.1145/1007965.1007970.

Kim, D., Song, Y., Braynov, S., \& Rao, H. R. (2005). A Multidimensional Trust Formation Model in B-to-C E-Commerce: A Conceptual Framework and Content Analyses of Academia/Practitioner Perspectives. Decision Support System, 40(2), 143-165. http://dx.doi.org/10.1016/j.dss.2004.01.006

Li, N., \& Zhang, P. (2005). Customer Online Shopping Behavior In J. Fjermestad \& N. Romano (Eds.). Customer Relationship Management. New York: M.E. Sharpe, Armonk.

Lin, W. B. (2007) The Exploration of Customer Satisfaction Model from a Comprehensive Perspective. Expert Systems with Applications, 33(1), 110-121. http://dx.doi.org/10.1016/j.eswa.2006.04.021

Lovelock, C. H. (1996). Service Marketing. New Jersey: Prentice-Hall.

Lovelock, C. H., Wirtz, J., \& Chew, P. (2009). Essentials of Services Marketing. Singapore: Prentice-Hall.

Massad, N., Heckman, R., \& Crowston, K. (2006). Customer Satisfaction with Electronic Service Encounter. International Journal of Electronic Commerce, 10(4), 73-104. http://dx.doi.org/10.2753/JEC1086-4415100403

Magnus, S., \& Rosengren, S. (2010). The Happy Versus Unhappy Service Worker in the Service Encounter: Assessing the Impact on Customer Satisfaction. Journal of Retailing and Consumer Services, 17(2), 161-169. http://dx.doi.org/10.1016/j.jretconser.2010.01.001

Mcknight, D., Choiudhury, V., \& Kacmar, C. (2002). Developing and Validating Trust Measures for E-Commerce: An Integrative Typology. Information Systems Research, 13(3), 334-359. http://dx.doi.org/10.1287/isre.13.3.334.81

Menor, L. J., \& Roth, A. V. (2007). New Service Development Competence in Retail Banking: Construct Development and Measurement Validation. Journal of Operations Management, 25(4), 825-846. 
http://dx.doi.org/10.1016/j.jom.2006.07.004

Meuterm, M. L., Ostrom, A. L., Roundtree, R. I., \& Bitner, M. J. (2000). Self-Service Technologies: Understanding Customer Satisfaction with Technology-Based Service Encounters. Journal of Marketing 64(3), 50-64. http://dx.doi.org/10.1509/jmkg.64.3.50.18024

Meuter, M. L., Ostrom, A. L., Bitner, M. J., \& Roundtree, R. (2003). The Influence of Technology Anxiety on Consumer Use and Experiences with Self-Service Technologies. Journal of Business Research, 56(11), 899-906. http://dx.doi.org/10.1016/S0148-2963(01)00276-4

Meuter, M. L., Bitner, M. J., Ostrom, A. L., \& Brown, S. W. (2005). Choosing Among Alternative. Service Delivery Modes: An Investigation of Customer Trial of Self- Service Technologies. Journal of Marketing, 69(2), 61-83. http://dx.doi.org/10.1509/jmkg.69.2.61.60759.

Morgan, R. M., \& Hunt, S. D. (1994). The Commitment-Trust of Relationship Marketing. Journal of Marketing, 58(3), 20-38. http://dx.doi.org/10.2307/1252308

Namasivayam, K. \& Hinkin, T. R. (2003). The Customer's Role in the Service Encounter: The Effects of Control and Fairness. Cornell Hotel and Restaurant Administrative Quarterly, 44(3), 26-34. http://dx.doi.org/10.1016/S0010-8804(03)90267-9

Noone, M. B., Kimes, E. S., Mattila, S. A., \& Wirtz, J. (2009). Perceived Service Encounter Pace and Customer Satisfaction: An Empirical Study of Restaurant Experience. Journal of Service Management, 20(4), 380-403. http://dx.doi.org/10.1108/09564230910978494

Parasuraman, A., Zeithaml, V. A., \& Berry, L. L. (1985). A Conceptual Model of Service Quality and its Implications for Future Research. Journal of Marketing, 49(4), 41-50. http://dx.doi.org/10.2307/1251430

Patricio, L., Fish, R., \& Cunha, J. (2003). Improving Satisfaction with Bank Service Offerings: Measuring the Contribution of each Delivery Channel. Managing Service Quality, 13(6), 471-482. http://dx.doi.org/10.1108/09604520310506531

Patterson, P. G.., \& Smith, T. (2001). Relationship Benefits in Service Industries: A Replication in a Southeast Asian Context. Journal of Service Marketing, 16(6), 425-443. http://dx.doi.org/10.1108/EUM0000000006098

Price, L. L., \& Arnould, E. J. (1999). Commercial Friendships: Service Provider-Client Relationships in Context. Journal of Marketing, 63(4), 38-56. http://dx.doi.org/10.2307/1251973

Raajpoot, N. (2004). Reconceptualizing Service Encounter Quality in a Nonwestern Context. Journal of Service Research, 7(2), 181-201. http://dx.doi.org/10.1177/1094670504268450

Reynolds, K. E., \& Beatty, S. E. (1999). Customer Benefits and Company Consequences of Customer-Salesperson Relationship in Retailing. Journal of Retailing, 75(1), 11-32. http://dx.doi.org/10.1016/S0022-4359(99)80002-5

Riley, M. (2007). Role Interpretation during Service Encounters: A Critical Review of Modern Approaches to Service Quality Management. Hospitality Management, 26(2), 409-420. http://dx.doi.org/10.1016/j.ijhm.2006.03.005

Shim, S., \& Eastlick, M. A. (1998). The Hierarchical Influence of Personal Values on Mall Shopping Attitude and Behavior. Journal of Retailin, 74(1), 139-160. http://dx.doi.org/10.1016/S0022-4359(99)80091-8

Singh, R., \& Tor, X. L. (2008). The Relative Effects of Competence and Likableness on Interpersonal Attraction, Journal of Social Psychology, 148(2), 253-255. http://dx.doi.org/10.3200/SOCP.148.2.253-256

Simon, F., \& Usunier, J. C. (2007). Cognitive, Demographic, and Situational Determinants of Service Customer Preference for Personnel-in-Contact over Self-Service Technology. International Journal of Research in Marketing, 24(2), 163-173. http://dx.doi.org/10.1016/j.ijresmar.2006.11.004

Sujan, H., Sujan, M., \& Bettman, J. R. (1998). Knowledge Structure Differences between More Effective and Less Effective Salespeople. Journal of Marketing Research, 25, 81-86. http://dx.doi.org/10.2307/3172927

Suprenant, C. F., \& Solomon, M. R. (1987). Predictability and Personalization in the Service Encounter. Journal of Marketing, 51(2), 86-96. http://dx.doi.org/10.2307/1251131

Sweeney, J. C., \& Webb, D. (2002). Relationship Benefits: An Exploration of Buyer-Supplier Dyads. Journal of Relationship Marketing, 1(2), 77-91. http://dx.doi.org/10.1300/J366v01n02_05

Thatcher, J. B., \& Perrewe, P. L. (2000). An Empirical Examination of Individual Trusts as Antecedents to Computer Anxiety and Computer Self-Efficacy. MIS Quarterly, 26(4), 381-396. http://dx.doi.org/10.2307/4132314. 
Walker, R. H., Margaret, C. L., Robert, H., \& Heather, F. (2002). Technology-Enabled Service Delivery: An Investigation of Reasons Affecting Customer Adoption and Rejection. International Journal of Service Industry Management, 13(1), 91-106. http://dx.doi.org/10.1108/09564230210421173

Wang, C. H., Hsu, L. C., \& Fang, S. R. (2009). Constructing a Relationship-Based Brand Equity Model. Service Business, 3(3), 275-292. http://dx.doi.org/10.1007/s11628-008-0062-2

Yoon, S. J. (2002). The Antecedents and Consequences of Trust in Online Purchase Decisions. Journal of Interactive Marketing, 16(2), 47-63. http://dx.doi.org/10.1002/dir.10008

Zhu, F. X., Wymer, W., \& Chen, I. (2002). IT-Based Services and Service Quality in Consumer Banking. International Journal of Service Industry Management, 13(1), 69-90. http://dx.doi.org/10.1108/09564230210421164

Table 1 . The reliability and construct validity of the constructs

\begin{tabular}{llccc}
\hline Constructs & \multicolumn{1}{c}{ Variables } & Eigenvalue & Extracted variance & \multicolumn{1}{c}{ Cronbach's alpha } \\
\hline IBSE & The level of interpersonal contact & 2.314 & 0.57851 & 0.7482 \\
\hline TBSE & The level of technology contact & 2.667 & 0.66665 & 0.8283 \\
\hline \multirow{2}{*}{ Relationship } & Special treatment benefit & 2.013 & 0.77818 & 0.7586 \\
benefits & Confidence benefit & 3.259 & 0.5863 & 0.9261 \\
& Social benefit & 2.492 & 0.57509 & 0.8933 \\
\hline
\end{tabular}

Table 2. Descriptive statistics and correlation matrix for the theoretical constructs

\begin{tabular}{lccccccccc}
\hline & Min & Max & Mean & S.D. & 1 & 2 & 3 & 4 & 5 \\
\hline 1. IBSE (4 items) & 1.39 & 4.85 & 3.68 & 0.47 & 1 & & & & \\
2. TBSE (4 items) & 2.11 & 4.34 & 3.18 & 0.39 & 0.538 & 1 & & \\
3. Special treatment benefit (4 items) & 1.08 & 4.28 & 2.23 & 0.53 & 0.369 & 0.393 & 1 & & \\
4. Confidence benefit (4 items) & 1.12 & 4.39 & 3.83 & 0.26 & 0.424 & 0.598 & 0.488 & 1 \\
5. Social benefit (3 items) & 1.25 & 5.00 & 3.29 & 0.67 & 0.721 & 0.655 & 0.583 & 0.516 & 1 \\
\hline
\end{tabular}

*The first four columns are descriptive statistics of each construct.

*All others are correlation coefficients in which are significant at the 0.01 level (2-tailed). 
Table 3. Standardized parameter estimates and fit indices

\begin{tabular}{lcc}
\hline Relationship & Hypotheses & Estimate (t-values) \\
IBSE $\rightarrow$ special treatment benefit & H1 $(V)$ & $0.275(4.191)$ \\
IBSE $\rightarrow$ confidence benefit & $\mathrm{H} 2(\mathrm{~V})$ & $0.497(5.493)$ \\
IBSE $\rightarrow$ social benefit & $\mathrm{H} 3(\mathrm{~V})$ & $0.793(6.553)$ \\
TBSE $\rightarrow$ special treatment benefit & $\mathrm{H} 4(\mathrm{~V})$ & $0.389(5.714)$ \\
TBSE $\rightarrow$ confidence benefit & $\mathrm{H} 5(\times)$ & $0.078(1.457)$ \\
TBSE $\rightarrow$ social benefit & $\mathrm{H} 6(\times)$ & \\
\hline Squared Multiple Correlation $\left(R^{2}\right)$ & & \\
Relationship quality $=0.237$ & & \\
Service brand equity $=0.501$ & & \\
$\chi^{2}=432.07$ & & \\
df $=145$ & & \\
CFI $=0.92$ & & \\
AGFI $=0.839$ & & \\
RMSEA $=0.078$ & & \\
\hline
\end{tabular}

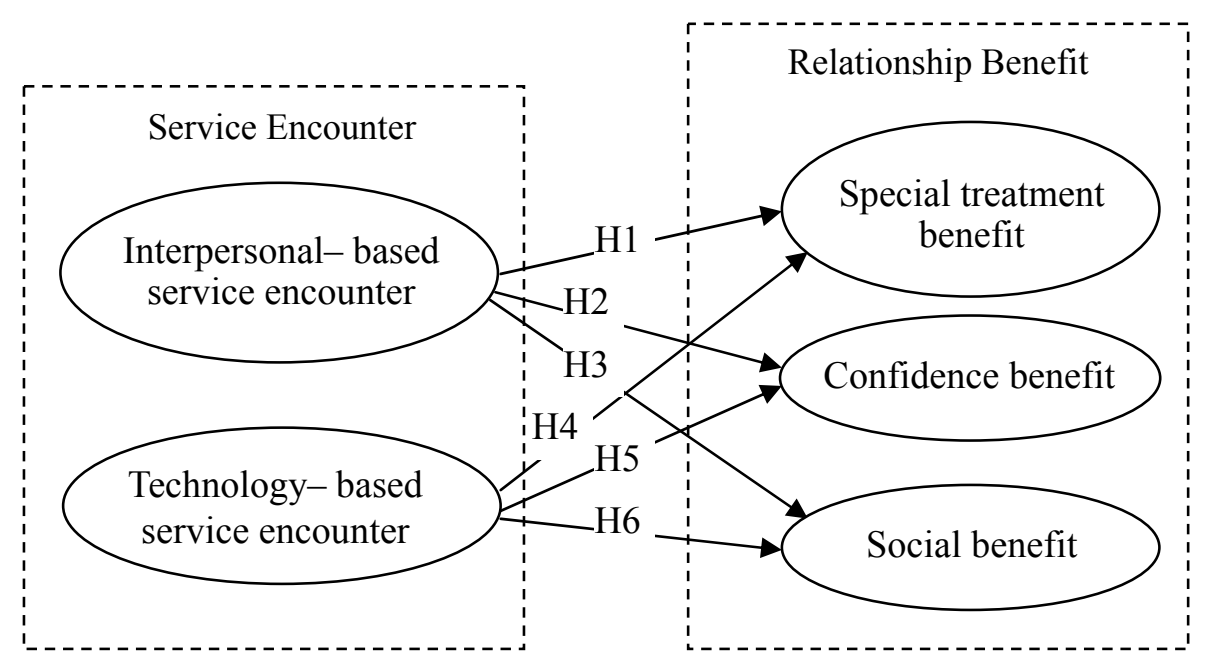

Figure 1. The conceptual model 